\title{
Implementation of an e-Commerce System for the Automation and Improvement of Commercial Management at a Business Level
}

\author{
Anthony Tupia-Astoray ${ }^{1}$ \\ Facultad de Ciencias e Ingeniería \\ Universidad de Ciencias y Humanidades \\ Lima,Perú
}

\author{
Laberiano Andrade-Arenas ${ }^{2}$ \\ Facultad de Ciencias e Ingeniería \\ Universidad de Ciencias y Humanidades \\ Lima,Perú
}

\begin{abstract}
At present micro and small businesses engaged in the production and marketing of products and have a single means of sale, whether stalls or physical stores, have been affected by the current crisis that is happening due to the pandemic, which came in early 2020 to Europe and different countries in Latin America, which is causing terrible damage to the economy of enterprises, since it does not have a means of virtual sales, where they can offer and market their products so that trade continues to operate during the pandemic. In this way, we designed a prototype e-commerce system meeting the requirements required by the organizations. Where it was based on the Scrum methodology as an agile development framework for the realization of the project. The use of the Marvel design tool allowed the creation of web platform prototypes. Obtaining as a result, prototypes according to an e-commerce system complying with the development procedures established by the Scrum team, which gives you a novel proposal and a productive approach to start implementing e-commerce within the sales processes of each business area. Therefore, this e-commerce system prototype proposal can be implemented by the different micro companies that wish to have a new online sales method and improve their commercial area process, allowing the increase of their client portfolio, as well as their production.
\end{abstract}

Keywords-Agile development; e-commerce; scrum methodology; prototype; system

\section{INTRODUCTION}

Currently, e-commerce is becoming a technological solution for the various problems that arise within companies in relation to their sales processes or business management.

e-Commerce is a growing phenomenon in Latin America and the world, so the study of its technological acceptance is high [1]. Having a virtual business tool favors and gives you a series of advantages such as: having access from any geographical area, being accessible 24 hours a day, having a favorable increase of customers and start to be competitive in the market, having information and control of customers accessing the system, in addition to reducing costs and minimizing service times and product deliveries.

For small and micro-enterprises, the use of the Internet and the development of e-commerce is an opportunity because it allows them to increase their capacity to disseminate products, make distance sales and make their cost structure more flexible [2]. e-Commerce drives advances in security and payment systems, marketing strategies and advertising, media distribution, business-to-business commerce and retailing [3]. People today use e-commerce constantly to make purchases of all kinds and rely on the security they offer when making an online transaction or payment. Businesses also have the ability to be more connected with their shoppers [4].

With the development of the Internet and other technologies, the efficiency of transactions will constantly improve [5]. Therefore, companies need to implement an e-commerce system to improve and automate the commercial management and can undertake a new business direction and provide a solution to their problems. It requires a system that provides a catalog of the company's products, has a reliable database to store the information that is generated from a customer purchase. All this opens you to have new sales opportunities and obtain new customers and therefore more production and sales. However, you will be able to manage a record of customers and sales made, have updated products and also with an adequate control.

The objective of the research work is to implement an e-commerce system that allows to automate and improve the processes of commercial management at the enterprise level, where companies have and count with new business opportunities.

The structure of the article consists of five sections: in Section II is the literature review, Section III details the methodology of the research study, in Section IV the case study will be visualized, in Section V, will consist of the results and discussions; finally in Section VI the conclusions are mentioned.

\section{REVIEW LITERATURE}

The development of technology and information has spread to various sectors, especially to the sector of product marketing and product transactions. The presence of e-commerce brings new changes in the world of production and business marketing [6]. This situation undoubtedly contributes to the optimization of processes and expands opportunities for companies in ecommerce. Clear and concise communication between the company and the consumer provides security and allows the identification of needs that, when met in a timely manner, enhance service and efficiency in the management and design of information [7]. 
The new information and communication technologies have revolutionized at the international level broad sectors of knowledge and human activities, fostering the emergence of new ways of doing business [8]. In this regard, it should be noted that the implementation of e-commerce and payment by credit card or cell phone via the Internet is vital for GuineaBissau's development.

Globalization requires countries and producers to innovate their ways of marketing in order to remain competitive in the market [9]. One alternative is to incorporate producers and micro and medium-sized enterprises into e-commerce successfully and analyze the results they have obtained by applying it, with the objective of improving their income. To this end, it is necessary to formulate models for the adoption of this form of business, which will allow agroindustrial companies to incorporate it into their daily activities so that they can be more productive.

e-Commerce in the level of sales of micro, small and medium-sized enterprises (MSMEs) of some key sectors of the city of Ibagué (Industry, Commerce and Services), for which we seek to know the current status of e-commerce and its importance, the causes of its use and non-use, and the positioning it has in the strategic plans of these organizations [10].

\section{Methodology}

\section{A. Scrum}

The Scrum methodology is an iterative process and evokes moments of feedback in a systematic way [11]. Accordingly, it was decided to develop the research work with the Scrum methodology. The technical framework of scrum, is formed by a set of practices and rules that respond to the following agile development principles: Evolutionary product management, instead of the traditional or predictive [12].

Scrum is an agile, lightweight framework that provides steps to manage and control the software and product development process [13]. Quality of the result based on the tacit knowledge of people, rather than on the explicit knowledge of the processes and technology used. Incremental development strategy through iterations (Sprint). scrum methodology is much more than group work. Therefore, it is encouraged to work according to their personal interests [14]. As shown in Fig. 1, the Scrum process scheme was made, which under its work techniques will execute the research development through the daylin scrum, retrospective, sprint review and taking into account the creation of the product backlog, sprint backlog and finally have a release.

1) Phase 1: Start: In this first phase, the project objectives will be analyzed to obtain product requirements and from there create the user stories.

2) Phase 2: Planning: In this phase the planning of the deliverables (Sprint) will be established, where sets of tasks to be performed by the development team will be established and meetings will be held to determine and discuss.

3) Phase 3: Implementation: The sprint is planned by means of a GANT diagram, where start and end dates of its development are established.

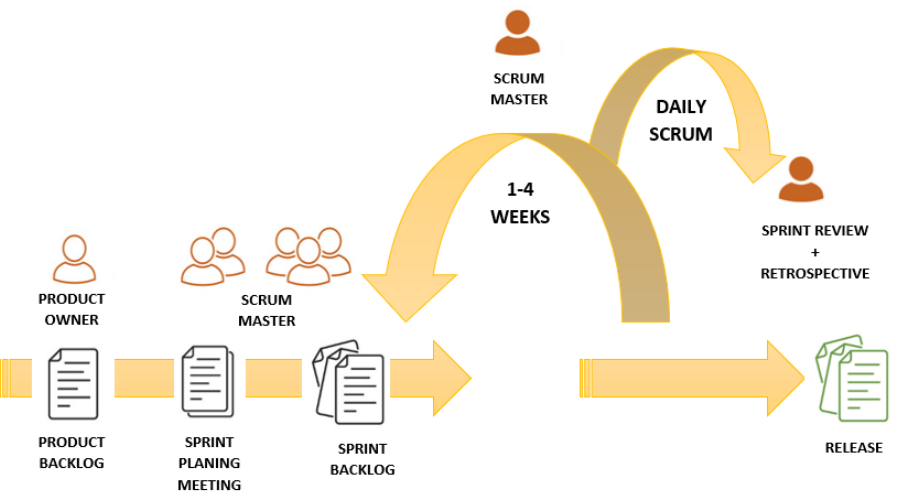

Fig. 1. Scrum Process

4) Phase 4: Review and Retrospective: In this phase, sprint retrospective meetings will be held to evaluate and discuss the sprint performed, taking into account the internal evaluation of the team's work.

5) Phase 5: Launch: This phase is the final part of the whole process where the complete and functional deliverables are reported for release.

\section{B. Prototype Tool}

The development of prototypes is the design vision of the system and how it is required to implement it in the future applying the requirements established by the client, that is why the following software will be used for the development.

1) Marvel: This tool allows you to develop or shape your design ideas through its work platform and generate design prototypes quickly.

\section{CASE STUdy}

In this section the research study was developed applying the methodology processes, fulfilling all the development of the prototype by executing the phases mentioned above.

\section{1) Phase 1: Start:}

a) Requirements: The requirements are part of the requirements established by the product owner who is in charge of collecting as much information as possible about how the system is intended to work and how it is visualized. Table I, shows the requirements that were made and that are functional.

TABLE I. REQUIREMENTS

\begin{tabular}{|c|c|}
\hline \multicolumn{2}{|r|}{ Requirements } \\
\hline$N^{\circ}$ & Item \\
\hline 1 & The system must be able to display the company's product catalog \\
\hline 2 & $\begin{array}{l}\text { The system should allow you to manage the shopping cart, add } \\
\text { products, delete products and cancel shopping cart }\end{array}$ \\
\hline 3 & $\begin{array}{l}\text { The system must allow the customer to purchase the products added } \\
\text { to the shopping cart }\end{array}$ \\
\hline 4 & $\begin{array}{l}\text { The System must allow to register the information of the clients as } \\
\text { natural person or company }\end{array}$ \\
\hline 5 & $\begin{array}{l}\text { The system shall allow adding new products, modifying and deleting } \\
\text { existing products }\end{array}$ \\
\hline 6 & $\begin{array}{l}\text { The system must allow to display a sales report. The data to be dis- } \\
\text { played are: date, sale number, customer name, product code, product } \\
\text { name, product quantity, unit price, total Soles }\end{array}$ \\
\hline
\end{tabular}


b) Backlog Product: The backlog is the ordered list of all the requirements previously established by the customer. In Table II, we observe the functional user stories and also the estimation and priority that helps to evaluate each user story.

TABLE II. BACKLOG PRODUCT

\begin{tabular}{|c|c|c|c|}
\hline \multicolumn{4}{|c|}{ Backlog Product } \\
\hline$N^{\circ}$ & Item & Priority & Estimate \\
\hline H1 & $\begin{array}{l}\text { As a user, I want to see the catalog of } \\
\text { the products in the system }\end{array}$ & High & 2 \\
\hline $\mathrm{H} 2$ & $\begin{array}{l}\text { As a user, I need to manage the purchase } \\
\text { of the products added to the shopping } \\
\text { cart }\end{array}$ & High & 1 \\
\hline $\mathrm{H} 3$ & $\begin{array}{l}\text { As a user, I want to register to the } \\
\text { system as a natural person or company }\end{array}$ & High & 2 \\
\hline $\mathrm{H} 4$ & $\begin{array}{l}\text { As a user, I wish to enter the system } \\
\text { through a login }\end{array}$ & High & 2 \\
\hline H5 & $\begin{array}{l}\text { As an administrator, I want to enter the } \\
\text { administrator module through a login }\end{array}$ & Medium & 1 \\
\hline H6 & $\begin{array}{l}\text { As an administrator, I want to add new } \\
\text { products, modify and delete existing } \\
\text { products }\end{array}$ & Medium & 3 \\
\hline $\mathrm{H} 7$ & $\begin{array}{l}\text { As an area manager, I would like to see } \\
\text { the sales reports for the day }\end{array}$ & Under & 1 \\
\hline
\end{tabular}

c) Estimate - Planning Poker: The planning poker was used to estimate the user stories and determine the effort it will take to develop each one, depending on its difficulty, which is why it was decided to use this technique. As shown in Table III.

TABLE III. PLANNING POKER

\begin{tabular}{|l||l||l|}
\hline \multicolumn{3}{|c|}{ Planning Poker } \\
\hline Item & Estimate & Time \\
\hline 1 & 2 & 2 days \\
\hline 2 & 1 & 1 day \\
\hline 3 & 2 & 2 days \\
\hline 4 & 2 & 2 days \\
\hline 5 & 1 & 1 days \\
\hline 6 & 3 & 3 days \\
\hline 7 & 3 & 1 days \\
\hline Total & 14 & 12 days \\
\hline
\end{tabular}

\section{2) Phase 2: Planning:}

a) Sprint Planning: The necessary activities were carried out to develop a new version of the product (Increment) of functional type, according to the specifications for the Sprint [15]. It was determined what will be the Sprint (Deliverables), by means of a tactical planning of work it was decided that it will be 4 sprint, for this work the sprint counted with two stories of users fully identified previously, as it is shown in Table IV.

b) Product Roadmap: In this section the Product Roadmap is established, which is a high-level plan that allows us to see how our product will evolve by launching the deliverables that were established, it is like our roadmap, which allows you to describe how to achieve the objectives or vision of the product to be delivered. All this can be seen in Fig. 2.

\section{3) Phase 3: Implementation:}

a) Sprint Planning Meeting: In this section the development of the tasks was organized based on a sprint chronogram where the dates of each deliverable were determined. It will help the work team to maintain an order when developing the
TABLE IV. SPRINT PLANNING

\begin{tabular}{|c|c|c|}
\hline \multicolumn{3}{|c|}{ Sprint Planning } \\
\hline$N^{\circ}$ & User History & $N^{\circ}$ Item \\
\hline Sprint 1 & $\begin{array}{l}\text { H1 As a user, I want to see the catalog of the } \\
\text { products in the system } \\
\text { H2 As a user, As a user, I want to see the product } \\
\text { catalog in the system }\end{array}$ & 1 \\
\hline Sprint 2 & $\begin{array}{l}\text { H3 As a user, I want to register to the system as } \\
\text { a natural person or company } \\
\text { H4 As a user, I want to enter the system through } \\
\text { a login }\end{array}$ & 2 \\
\hline Sprint 3 & $\begin{array}{l}\text { H5 As an administrator, I want to enter the ad- } \\
\text { ministrator module through a login } \\
\text { H6 As an administrator, I want to add new prod- } \\
\text { ucts, modify and delete existing products }\end{array}$ & 3 \\
\hline Sprint 4 & $\begin{array}{l}\text { H7 As an area manager, I would like to see the } \\
\text { sales reports for the day. }\end{array}$ & 4 \\
\hline
\end{tabular}

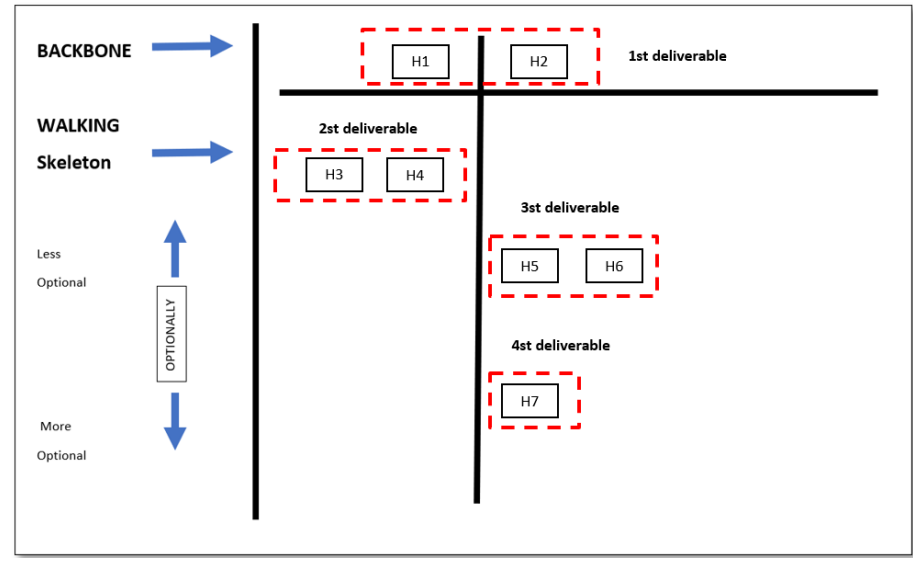

Fig. 2. Product Roadmap

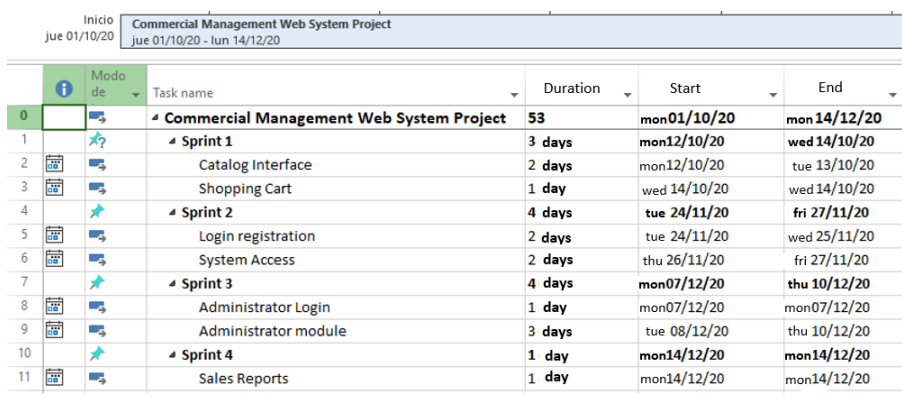

Fig. 3. Sprint Timeline

product. The schedule with the items established in the sprint planning is shown in Fig. 3.

\section{4) Phase 4: Review and Retrospective:}

a) Daily Scrum: All the people involved in the project will meet daily to review the sprint and determine if there is any inconvenience that can be improved or solved. The people involved in the meetings rotated daily every day, with the sole purpose of ensuring that the objective was met and developed normally and without problems. They analyzed what was done wrong, what was done right and what difficulties were encountered that did not allow the project to continue as planned [16].

5) Phase 5: Launch: 


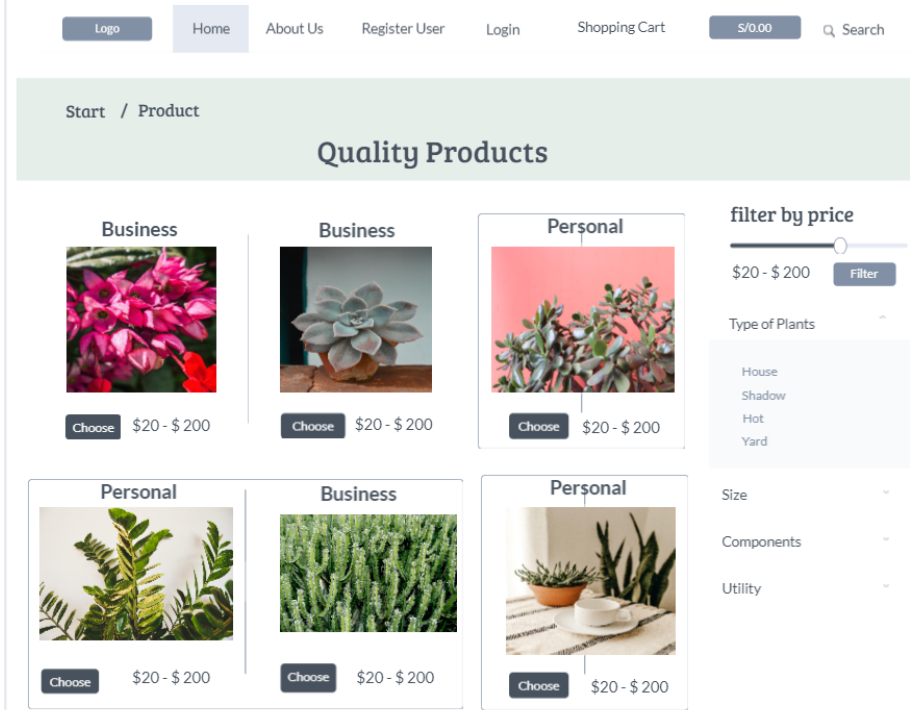

Fig. 4. Product Catalogue

a) Sprint 1: It is based on the first deliverable of the system, where the company's product catalog is displayed, and apart from that, the shopping cart is displayed, which will serve to complete the system's purchase flow. These two are important functionalities for the management of the eCommerce, that is why it was determined to be the first deliverable because it provides value and functionality to the system, as shown in Fig. 4, the user will be able to visualize the product catalog, then the product will have a main window, where the main characteristics will be shown and also the item can be added to the cart, all this is shown in Fig. 5. Then, we have the shopping cart interface where it will detail how the purchase will be made and what will be the type of payment to be made, as shown in Fig. 6 .

b) Sprint 2: This is the second deliverable of the system, it consists of two interfaces that will be used for the user to $\log$ in to the system after he/she has registered, therefore, an interface for the creation of new users was also created, as shown in Fig. 7. The user registration prototype was also added, where new clients who are interested in having some interaction with the web system can be registered (Fig. 8).

c) Sprint 3: It is the third deliverable of the system, it is about the interfaces to the access of the administrator module as shown in Fig. 9, so that the administrator can enter the module, before he must $\log$ in, previously registered in the system and have the user data registered in the database, then, he must fill in the fields shown in the interface of email and password, then he will be directed to the administrator module shown in Fig. 10. Where he can manage the products according to the criteria of the company, in sum, he will have administrator permissions to different actions such as deleting, viewing and updating the product.

d) Sprint 4: It is the fourth deliverable of the system, the interface was made to show all the reports of the sales that

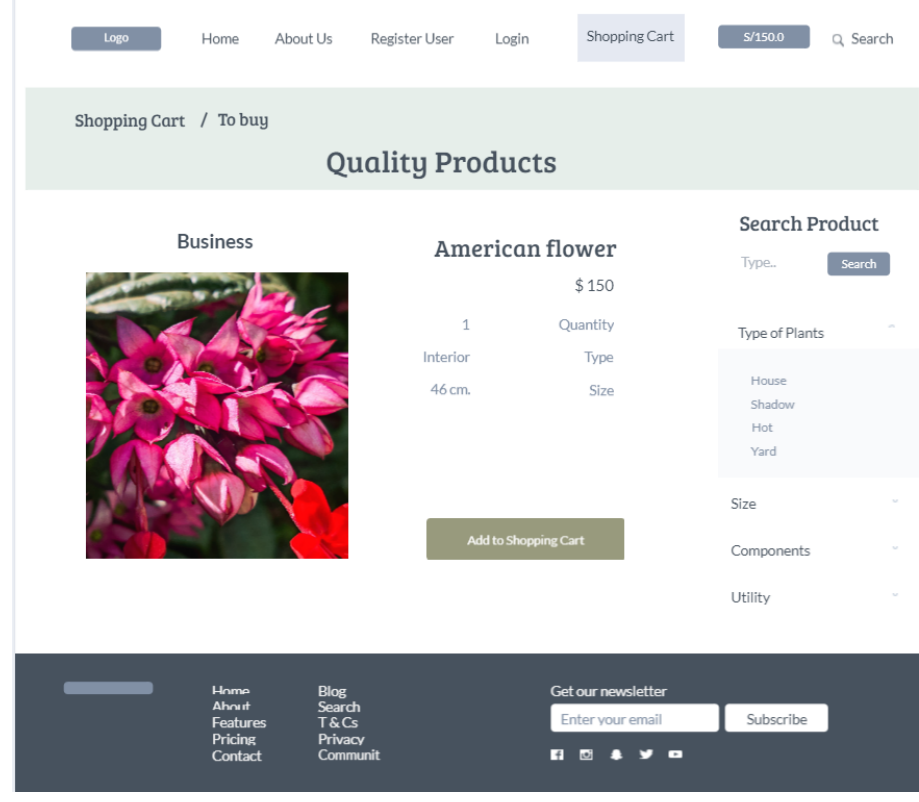

Fig. 5. Purchase Prototype

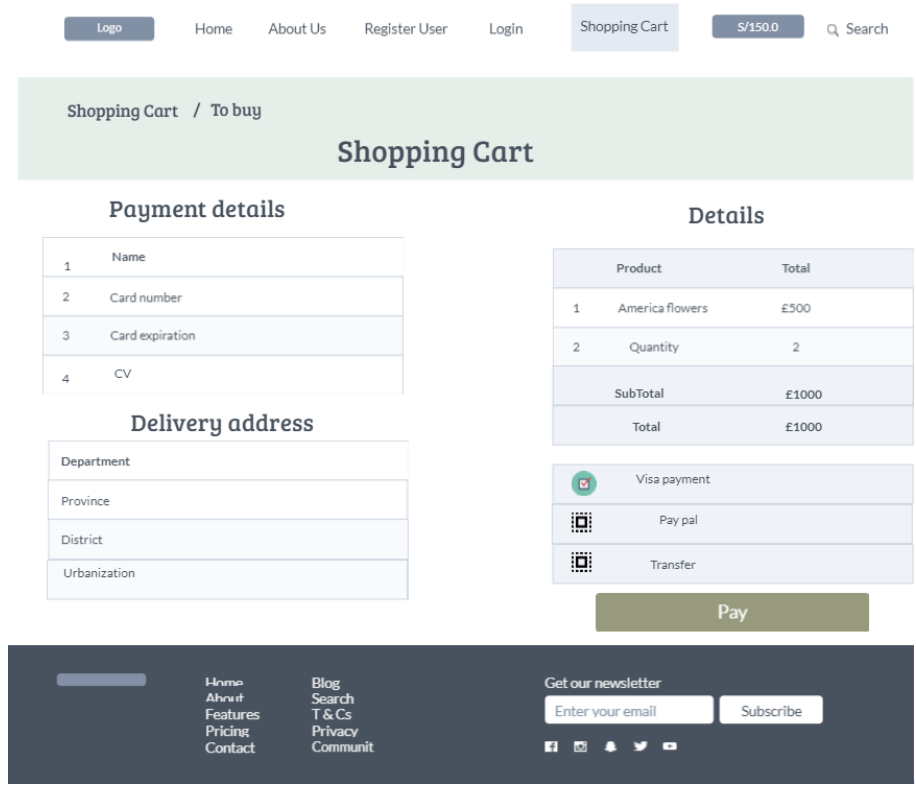

Fig. 6. Shopping Cart Prototype

are made daily, where the area manager can view the items that were part of the purchase of customers, also showing the name and image of the product that was purchased. The area manager can also perform different actions on the product, as shown in Fig. 11.

\section{Results And Discussions}

\section{A. About the Case Study}

The main objective of the study is to develop an ecommerce web system, which is capable of allowing companies to have new sales opportunities through internet com- 


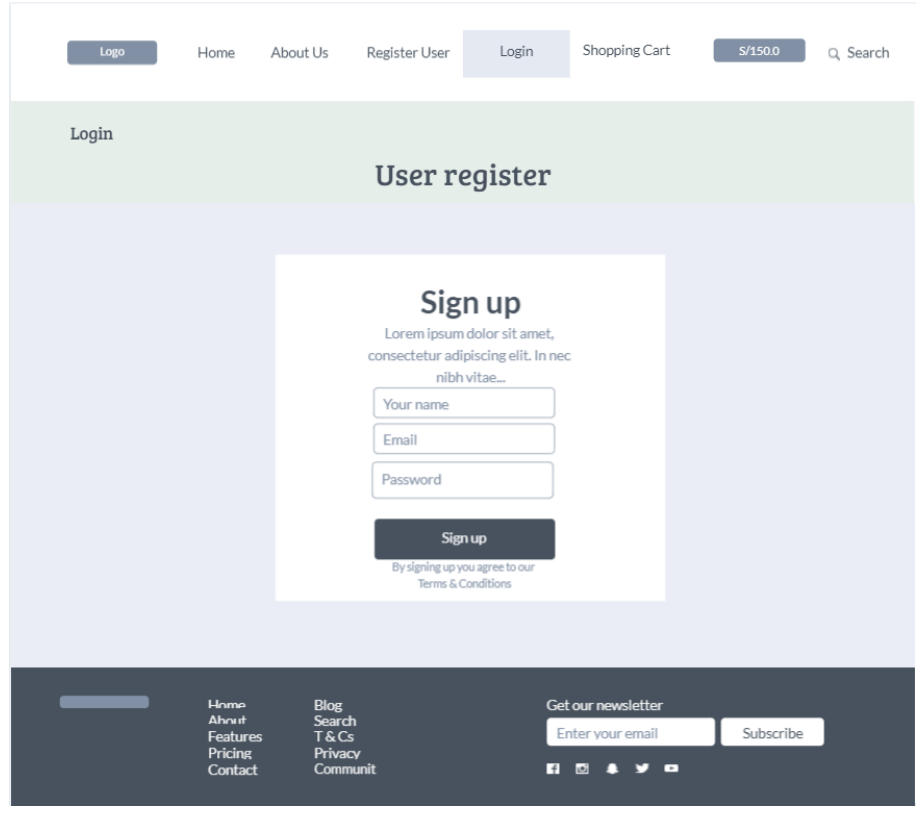

Fig. 7. Registration Prototype

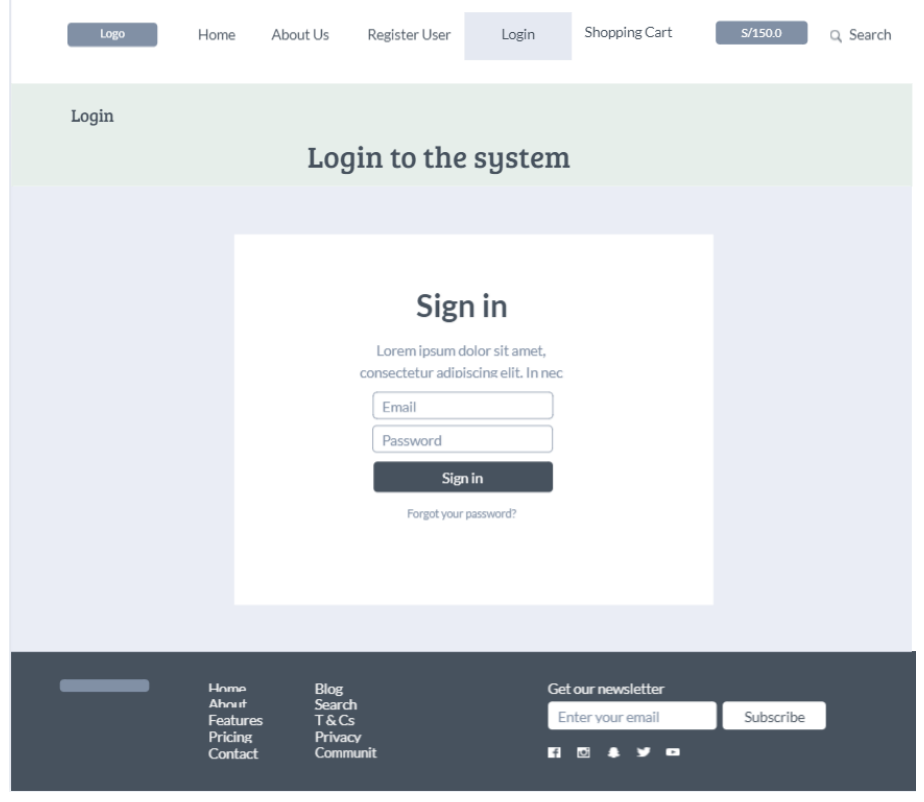

Fig. 8. Login Prototype

merce. The implementation. of new commercial methods aimed primarily at meeting the needs of consumers should include the monopolization of sales markets, global competition and active development of information technologies [17].

It is a good way to take advantage of new technologies and be able to solve the problems that arise in organizations. The development of the prototypes presented was elaborated by a tool called Marvel, it is a web tool that allows you to transform your design ideas into digital products, which gives you a series of components that facilitate the creation of it, apart from being unique. Eight prototypes were made within this tool, each one with different functionalities which will be
ADMINISTRATION MODULE

Login to the system

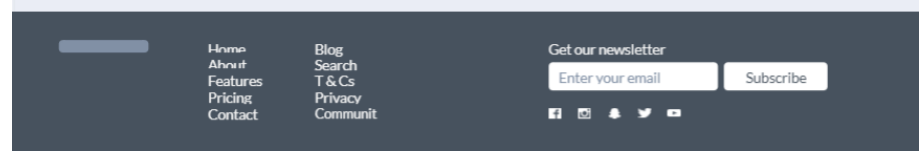

Fig. 9. Admin Login Prototype

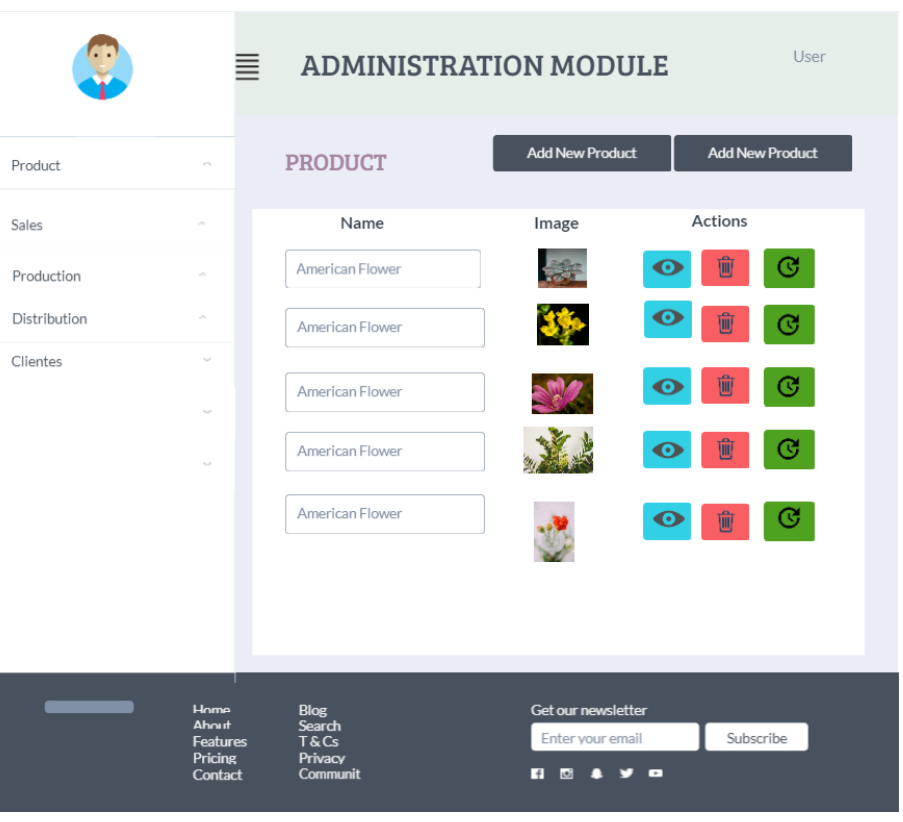

Fig. 10. Product Management Prototype

explained below.

1) Sprint 1: Sprint 1, has the development of 3 prototypes which are: Product catalog prototype, is the face of the web system, not to say, the presentation and the first thing the user will see, therefore, components were implemented which will make it look interesting and novel. The shopping cart prototype was developed with the functionality to start the purchase flow starting from the product selection. The shopping cart prototype is the final part of the flow, where the payment method and product details are detailed. 


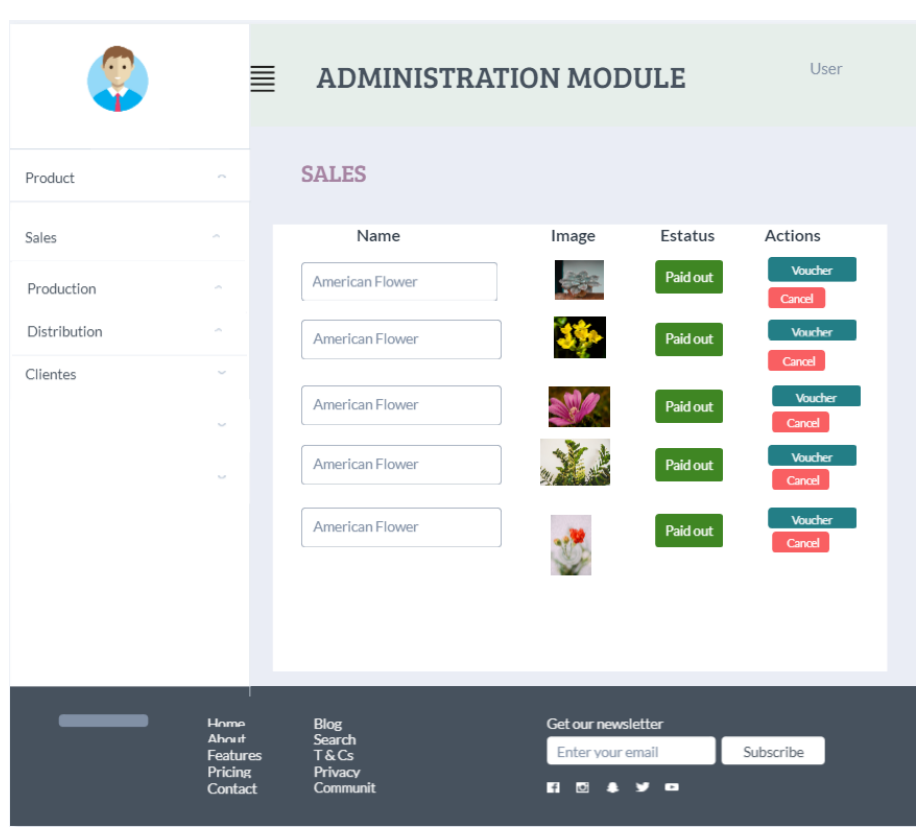

Fig. 11. Sales Record Prototype

2) Sprint 2: Sprint 2, has developed 2 prototypes which are: User Registration Prototype which was determined to create this interface for the registration of persons or companies that wish to register to the system and can have records within it. A basic form was added with three fields to fill out and a button to confirm the registration. Prototype of Login to the system, is where the user will $\log$ in that allows you to have access to more features and to buy within the page, has two fields of email and password.

3) Sprint 3: Sprint 3 has developed 2 prototypes that are part of the administrator page and does not involve the client: Administrator Module Login Prototype, which has a form with two text fields and a Login button. Product Management Prototype, which is the administrator module. This interface shows details of the products published in the e-Commerce which can be modified, deleted, updated, as well as adding new products.

4) Sprint 4: Sprint 4 has 1 development prototype, which is the Sales Registration Prototype. A field was created where the daily sales reports are shown, where the products are detailed with their respective images and status of the items, in addition, actions were added so that the area manager has access to modify any sale if necessary.

\section{B. About the Methodology}

1) Advantages: One of the advantages of Scrum is to provide organization and collaborative work of the team members and is adaptable to the changes that can be generated in the construction of the project [18]. As well as having deliverables periodically and not at the end of the project [19].

2) Disadvantages: One of the disadvantages of Scrum is that it requires people capable of managing large projects and who have adequate academic training. Another negative circumstance is that this methodology is misused in development teams, as it does not comply with the values and principles that Scrum proposes [18].

3) Comparisons: The agile methodology that we have used for the development of the project is Scrum, one of the agile methodologies that is currently being widely used and consequently is becoming one of the best, bringing benefits to companies, in addition to the fact that Scrum is capable of managing difficult projects. Scrum is basically an agile and lightweight framework that provides the steps to manage and control the process of software and product development . This is why we are going to make a comparison with a traditional Cascade methodology. Cascade makes a procedural and rigid evaluation, which sometimes does not allow the interaction between processes and techniques, because of its rigorous disposition, does not allow an adequate flow of information that allows to know in an integral way the needs of the client [20]. With everything mentioned above in Table V, the comparison of these two methodologies already mentioned was made, where the important characteristics of each one were named.

TABLE V. COMPARISON CASCADE - SCRUM

\begin{tabular}{|l||l|}
\hline Traditional Methodology (Waterfall) & Agile Methodology(Scrum) \\
\hline It has different stages & consists of periodic deliverables (Sprint) \\
\hline Does not accept any kind of change & Is able to accept changes \\
\hline Cost is determined during planning & Cost is determined during the project \\
\hline $\begin{array}{l}\text { The development team is flexible with } \\
\text { limited creative capacity }\end{array}$ & $\begin{array}{l}\text { The development team is flexible with } \\
\text { unlimited creative capacity }\end{array}$ \\
\hline Sequential & Overlay \\
\hline
\end{tabular}

\section{CONCLUSiOn AND Future Work}

Finally, in this research, the whole prototyping of the interfaces of the web system that was developed to improve the commercial management, as well as to have new sales opportunities and to face the problems that the company is facing. And to do it now by means of the electronic commerce that is a window that the new technologies allow you to use. All this was carried out thanks to the Marvel tool that has interesting mechanisms and components that made the design ideas take shape as they are, and can be visualized in a realistic way. The methodology used for the good development of the web system was Scrum, which allowed us to carry out the project in a more orderly and efficient way at the time of its development. In my article, as future work, I recommend that the prototypes presented and designed be implemented and put into development. Where micro and small companies have the opportunity to undertake and have a new sales method for their business.

\section{REFERENCES}

[1] J. F. T. Mesías, J. C. S. Giraldo, and B. B. Díaz, "Aceptación del ecommerce en colombia: un estudio para la ciudad de medellín," Revista Facultad de Ciencias Económicas: Investigación y Reflexión, vol. 19, no. 2, pp. 9-23, 2011.

[2] G. A. Barrera, "Relación de capacitación con adopción de internet y ecommerce: Diferencias entre microemprendedores de chile," Información tecnológica, vol. 28, no. 6, pp. 61-70, 2017.

[3] K. C. Laudon, C. G. Traver et al., E-commerce: business, technology, society, 2016.

[4] P. Barrientos Felipa, "Marketing+ internet= e-commerce: oportunidades y desafíos," Revista Finanzas y Política Económica, Vol. 9, no. 1 (ene.jun. 2017); p. 45-56. http://dx. doi. org/10.14718/revfinanzpolitecon. 2017.9. 1.3, 2017. 
[5] Y. Huang, Y. Chai, Y. Liu, and J. Shen, "Architecture of next-generation e-commerce platform," Tsinghua Science and Technology, vol. 24, no. 1, pp. 18-29, 2019.

[6] D. S. Islamiati, D. Agata, and A. R. Anom Besari, "Design and implementation of various payment system for product transaction in mobile application," in 2019 International Electronics Symposium (IES), 2019, pp. 287-292.

[7] H. Chaparro Cuartas et al., "Implementación de una plataforma ecommerce para la compañía promo electric."

[8] V. L. Sanabria Díaz, L. A. Torres Ramírez, and L. M. López Posada, "Comercio electrónico y nivel de ventas en las mipymes del sector comercio, industria y servicios de ibagué," Revista EAN, no. 80, pp. 132-154, 2016

[9] D. E. SEPULVEDA ROBLES, D. SEPULVEDA JIMENEZ, F. PEREZ SOTO, E. FIGUEROA HERNANDEZ et al., "Propuesta de modelo para adopción del comercio electrónico en empresas del sector agroindustrial en méxico," 2014

[10] S. Lin and X. Wenzheng, "E-commerce personalized recommendation system based on web mining technology design and implementation," in 2015 International Conference on Intelligent Transportation, Big Data and Smart City, 2015, pp. 347-350.

[11] J. Vogelzang, W. F. Admiraal, and J. H. van Driel, "Effects of scrum methodology on students' critical scientific literacy: the case of green chemistry," Chemistry Education Research and Practice, 2020.

[12] J. P. I. Alexander Menzinsky, Gertrudis López, "Scrum master," Scrum, pp. 2-94, 2016

[13] A. Srivastava, S. Bhardwaj, and S. Saraswat, "Scrum model for agile methodology," in 2017 International Conference on Computing, Communication and Automation (ICCCA), 2017, pp. 864-869.

[14] A. Jurado-Navas and R. Munoz-Luna, "Scrum methodology in higher education: Innovation in teaching, learning and assessment." International Journal of Higher Education, vol. 6, no. 6, pp. 1-18, 2017.

[15] J. C. A. Becerra and C. E. D. Vanegas, "Propuesta de un método para desarrollar sistemas de información geográfica a partir de la metodología de desarrollo ágil-scrum." Cuaderno Activa, vol. 10, pp. 29-41, 2018.

[16] D. X. Sarango Yunga, "Desarrollo de plataforma web para la evaluación de software basado en la metodología scrum," B.S. thesis, Machala: Universidad Técnica de Machala, 2020.

[17] A. Kwilinski, R. Volynets, I. Berdnik, M. Holovko, and P. Berzin, "Ecommerce: Concept and legal regulation in modern economic conditions," Journal of Legal, Ethical and Regulatory Issues, vol. 22, pp. $1-6,2019$.

[18] D. R. Garcia Cercado, "Factores que afectan la productividad del equipo scrum: Una revisión sistemática de la literatura," 2019.

[19] A. Srivastava, S. Bhardwaj, and S. Saraswat, "Scrum model for agile methodology," pp. 864-869, 2017.

[20] F. González González, S. L. Calero Castañeda et al., "Comparación de las metodologías cascada y ágil para el aumento de la productividad en el desarrollo de software," Ph.D. dissertation, Universidad Santiago de Cali, 2019. 